\title{
NEOPROTEROZOIC SUBSTRATE CONDITION VIS-À-VIS MICROBIAL MAT STRUCTURE AND ITS IMPLICATIONS: SONIA SANDSTONE, RAJASTHAN, INDIA
}

\author{
Pradip Samanta* $^{1}$, Soumik Mukhopadhyay ${ }^{2}$, Subir Sarkar $^{2}$ and Patrick George Eriksson ${ }^{3}$ \\ ${ }^{1}$ Durgapur Government College, Durgapur-713214, India \\ ${ }^{2}$ Department of Geological Sciences, Jadavpur University, Kolkata-700032, India \\ ${ }^{3}$ Department of Geology, University of Pretoria, Pretoria 0002, South Africa \\ *Corresponding Author; e-mail address: samanta.pradip@gmail.com (P. Samanta); \\ Telephone No.: +919433116101 (Mob.)
}

\begin{abstract}
The present study deals with the Neoproterozoic mat-infested substrate sculptured by inferred boiturbations, excellently preserved within the ca. 600 Ma Sonia Sandstone, northwest India. The bioturbations are horizontal, being preserved on the bed-surfaces and have been classified into linear grooves and discoidal structures. The linear grooves are of two types, one group represents a straight to meandering pattern with raised sand ridges on either side, while the other group represents a mostly meandering pattern with changing width along the length, without raised ridges. Both types of grooves resemble trails of advanced organisms. The discoidal structures have five internal lobes emerging from the centre and merging with the outer ring and may
\end{abstract}


represent body impressions of an organism; alternatively may represent variants of Ediacara or other soft bodied organisms. The interaction of the substrate with these possible bioturbators has great significance in establishing the evolutionary history of the substrate and resulting bioturbations during the Proterozoic. Microbial mats possibly provided oxygen and nutrients to he organisms and played an important role in their preservation. The study also tries to extrapolate the life style of these trace-makers. All these traces may raise speculation about the onset-time of some higher order organisms.

Keywords: Sonia Sandstone, Bioturbations, Microbial mat, Medusoid structure, Life style.

\section{Introduction}

Life began on the Earth perhaps before 3.8 Ga (cf., Reysenbach and Cady, 2001), thereafter for another 3 Ga the earth belonged solely to the microbiota (Schopf, 1999). The mesoscopic and megascopic organisms probably appeared during the Meso- to Neoproterozoic (Knoll and Carroll, 1999; Martin et al., 2000; Knoll et al., 2004) and many soft bodied organisms reached heir acme in the Neoproterozoic (Narbonne, 2005). The most discussed of these megascopic organisms are the Ediacaran fauna that are considered to follow the Neoproterozoic glaciations at 750 - $635 \mathrm{Ma}$, with maximum diversity during 560 - 540 Ma (Waggoner, 2003; Meert et al., 2011). However, records of bioturbations of such soft bodied life during this period are rare to sporadic and almost exclusively recorded from siliciclastic settings (Hoffmann and Mountjoy, 2001). Overall, the Neoproterozoic substrate condition was unique and was characterized by the presence of microbial mat colonies (resulting in new sets of structures; e.g., "MISS", Noffke et 
al., 2001; Noffke, 2010 or e.g., "MRS”, Eriksson et al., 2010; Sarkar et al., 2014) associated with the Proterozoic soft bodied organisms, including Ediacaran fauna (Gingras et al., 2011a). The microbial mats and these soft bodied organisms proliferated together, in other words, the soft bodied organisms grew on the then mat-infested seafloor making the close association between mat-related structures and traces of such organisms inherent obvious. These common associations sometimes create controversies. However, sponge-like fossils have recently been reported from Namibia of ca. $760 \mathrm{Ma}$ age (Brain et al., 2012) and, although controversial, structures interpreted as colonial multi-cellular organisms from Gabon are dated at ca. 2.1 Ga (Albani et al., 2010). Many published accounts of biotic evidence of presumptive traces of soft bodied organisms from this period have been reinterpreted and reconsidered as microbial mat colonies, microbial mat remnants (cf. Banerjee et al., 2010), or pseudofossils (Retallack, 2012) and thus the range of variation of fossil records remains uncertain (Seilacher, 1999, Banerjee et al., 2010). Nevertheless, there are some examples that are in reality very difficult to understand whether they are biogenic, purely physical in origin, or results of interaction between biogenic and physical processes.

In the present paper some possible bioturbations of mesoscopic organisms from the ca. 600 Ma Sonia Sandstone (Sarkar et al., 2008) of the Jodhpur Group (Marwar Supergroup), western Rajasthan, India are described. Though very restricted in occurrence, these possible bioturbations are found on the fresh surfaces of bedding plane exposures and are unique in their appearance and morphology, showing close resemblance to Phanerozoic counterparts. Noteworthy is that these structures show close association with a wide spectrum of microbial mat-related structures (Gerdes et al., 2000; Parizot et al., 2005; Sarkar et al., 2008; Eriksson et al., 2010; Samanta et al., 2011), but do not share morphological similarities with any of them. 
On the other hand, recent findings of Acritarchs from different horizons of the Marwar Supergroup (cf. Prasad et al., 2010) and of Cruziana from the immediately overlying Girbhakar Sandstone Formation (Kumar and Pandey, 2008) suggest the possibility of the presence of mesocopic life within the Sonia Sandstone, although no intact body fossil has so far been

reported. The purpose of this paper is to emphasize that the range of morphologic variations of organisms and related bioturbations during the Neoproterozoic could have been more diversified than they have so far been speculated to have been. As the acme of Ediacaran and other softbodied fauna is around 560 - $540 \mathrm{Ma}$, the age-equivalent Sonia Sandstone (Sarkar et al., 2008) may possibly be a perfect contender to exhibit such a wide range of variations in life-forms. Proterozoic substrate conditions become significant in extrapolating and extracting information about their behavioural attributes including movement, locomotion and interaction with the substrates during deposition of the ca. 600 Ma Sonia Sandstone in the absence of remains of these bioturbators. Keeping in view the age of the Sonia Sandstone, the detailed study of these possible bioturbations and the prevalent substrate condition, can possibly unravel a significant part in evolution of the early life.

\section{Geological Setting}

The present paper deals with the shallow marine interval of the unmetamorphosed and undeformed Sonia Sandstone, belonging to the Marwar Supergroup, that are exposed immediately north of Jodhpur city, Rajasthan, India (Fig. 1; Pareek, 1981). The Marwar Supergroup is exposed in an elongated area and is bounded by basin-margin fault systems 


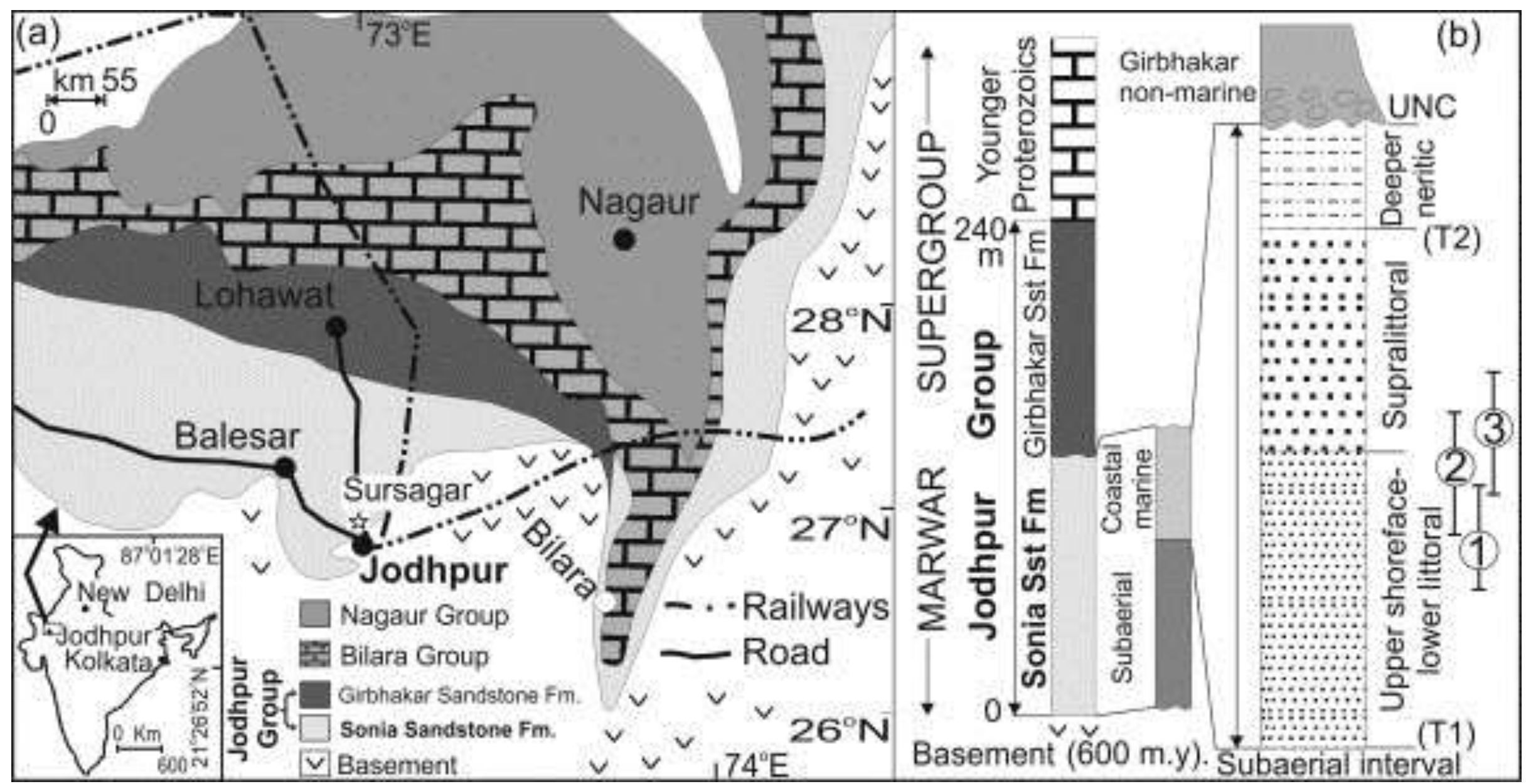

Fig. 1. Geological background of the study area: Geological sketch map showing distribution of the Sonia Sandstone and associated younger Ediacaran formations. Asterisk within the map represents the location of the area from where the inferred bioturbations are reported $($ Fm. $=$ Formation) (a). The relevant stratigraphic column and subdivisions of the Sonia Sandstone Formation are shown on the right. The palaeoenvironmental ranges of the marine segment of the Sonia Sandstone have also been shown. Note that the stratigraphic age of the dated rock (basement) has been mentioned. UNC $=$ Unconformity and $\mathrm{T}=$ Transgressive lag. Also note that the stratigraphic position of bioturbations for the individual type has been shown in the stratigraphic column: 1. Burrow with intact roof, 2. Trails with spill-over sand and 3. Discoidal structures (b). Map of India within inset showing the location of the study area. 
trending roughly NNW-SSE and N-S (Sarkar et al., 2012). Geophysical investigation suggests that the Bouger gravity anomaly contours are widely spaced and values ranging between -10 mgals and -30 mgals indicate that the basin was relatively shallow with a very thin sediment cover (Balakrishna, 1980; Chauhan, 1999). The deposition is inferred to have taken place in an intracratonic rift or a sag basin (Chauhan, 1999; Samanta, 2009; Sarkar et al., 2012).

The Marwar Supergroup is divisible into three groups, namely, the Jodhpur Group, Bilara Group and the Nagaur Group in ascending order (Fig. 1a). The Sonia Sandstone is the lowermost formation of the Jodhpur Group of the Marwar Supergroup (Fig. 1a). This sandstone is subdivided into two intervals, the lower subaerial interval and the upper coastal marine interval (Fig. 1b; Sarkar et al., 2005; Samanta, 2009; Samanta et al., 2011). This formation is thought to be of Neoproterozoic age (ca. $600 \mathrm{Ma}$ ) on the basis of radiometric dating of acid volcanic rocks (Rathore et al., 1996; 1998) that unconformably underlies the formation (Paliwal, 1998; Malone et al., 2008; Sarkar et al., 2005; 2008). The base of the coastal marine interval is marked by a transgressive lag and is unconformably overlain by the non-marine interval of the Girbhakar Sandstone Formation (Samanta, 2009; Samanta et al., 2011; Sarkar et al., 2012). The thickness of the coastal marine interval is about $60 \mathrm{~m}$ and it is composed of three facies ranging in inferred palaeogeography from deeper neritic to supralittoral (Fig. 1b; Sarkar et al., 2008; Samanta, 2009). The lower facies, characterized by repeated alternations between planar laminae and cross-laminae (facies A), strongly suggests deposition in the upper shoreface (Hill et al., 2003). However towards the top of this facies are preserved some rare remnants of washed out dunes, local bi-modal and bi-polar cross-strata orientations, diverse wave ripple orientations and interference ripples, indicating building up to the lower littoral setting. The middle facies (facies B), is characterized by planar laminae, infrequent wave ripples and rill marks, and indicates 
deposition in the littoral zone (Sarkar et al., 2008). Occurrence of adhesion laminae, translatent strata, grainfall-grainflow cross-strata of aeolian origin towards the top of this facies indicates a depositional palaeo-environment extending up into the supralittoral zone. The upper facies (facies C) is characterized by cosets of trough cross-strata separated by granular wave-winnowed lags that are stacked vertically in relatively less well sorted sandstones (Sarkar et al., 2008). The facies lacks any emergence features, thus depicting likely deposition in a neritic environment, possibly at a somewhat deeper zone than that inferred for facies A. The transition of facies B gradationally above facies $\mathrm{A}$, allied to the coarsening- and thickening-upward succession within this facies succession is a clear indication of progradation. Nevertheless, the upward transition of facies $\mathrm{B}$ to facies $\mathrm{C}$ is rather sharp and is characterized by a distinct granular lag sheet interpreted to be a transgressive lag (Fig. 1b; Sarkar et al., 2014). Facies C is coarsening- and thickeningupward within itself (Sarkar et al., 2008). The inferred bioturbations are present within Facies A and B that also contain abundant microbial mat related structures (Table I).

\section{Inferred bioturbations from the Sonia Sandstone}

The present paper deals with the biogenic structures inferred within facies A and B of the coastal marine interval of the Sonia Sandstone Formation and are reported from the Sursagar mines area, Jodhpur, Rajasthan, northwestern India (Fig. 1a). They are unique in appearance and morphology and can be grouped into two broad categories, described below.

\subsection{Linear structures on bedding planes}


Table 1. Classification and distribution of microbial mat related structures in the marine interval of the Sonia Sandstone; classification scheme after Sarkar et al. (2008).

\section{Microbial mat-related structures}

\section{Distribution}

Mat-layer discoidal: These are microbial mat colonies that appear at first sight as a packed assemblage of laterally growing "stromatolites", instead of normal vertical growth ( Fig. 11a). It is confined as a thin sheet on the bedding plane of only about $2 \mathrm{~mm}$ thickness, is internally massive, and has a planar nonerosional base, which is wavy on wave-rippled surfaces. It comprises of a cluster of disc-shaped bodies characterized by concentric rims, the cores of which are circular or oval-shaped mutually interlinking small chip-like bodies having no definite geometry. The discs are crenulated in appearance resulting from their being made up of discrete small outward-convex spindles Mat-layer crumpled: This structure is made up of a submillimetre-thick sheet Mat-layer on a wave rippled bedding plane that is crumpled, showing horizontal drag folds in diverse orientations, without any relation to the underlying wave ripple crests ( Fig. 11b). Underlying wave ripples are exposed only beyond its frayed preservational edges. Vertical height of the folds and spacing between them are up to $7 \mathrm{~mm}$ and $12 \mathrm{~cm}$, respectively

Mat-layer wrinkled: Diverse kinds of wrinkles which may be laterally continuous or discontinuous, are observed on bedding planes of the Sonia Sandstone. Wrinkle sets of diverse orientations may be superimposed one above another ( Fig. 11c). These are often represented by close-set rows of minute spindle-shaped bodies. Wrinkles having strong asymmetry in profile, with the steeper flank sometimes maintaining a broad similar orientation Mat-induced cracks: Cracks on sandstone bedding planes of different morphologies - like rectangular, polygonal, meandering or circular - are common within the Sonia Sandstone ( Fig. 11d). These cracks do not generally Facies A, B maintain any relation with bed surface primary structures and often cut across each other

Mat- Mat-induced bulge: Bulges of various shapes and sizes often surrounded by induced minute ridges are found on sandstone bed-surfaces (Fig. 11e), some of which on the same bed surface have small crater-like depressions defined by slightly raised rims at their centres. The bulges often have their high-angle flanks up to $45^{\circ}$

Mat-induced ridges: Similar to cracks, many of the sandstone bed surfaces exhibit linear, rectangular, polygonal and spindle-shaped ridges ( Fig. 11f); 
except for the parallel ones, they often cut across each other

Mat-protected setulfs: These structures resemble inverted flutes on bed surfaces ( Fig. 11g), and were first reported from a modern beach and named as setulfs by Friedman and Sanders (1974). These are found in swarms, exhibit positive relief, are elongated in form, distinctly steep at one end and flaring at Facies B the other, and are strongly unidirectional in orientation. Their orientation differs from that of associated asymmetric wave-current combined flow ripples, but matches the orientation of aeolian cross-strata ( Sarkar et al., 2008) Mat-protected patchy ripples: The same bedding plane surfaces of Sonia

MatSandstone often exhibit ripples with the same geometry and orientation in protected discrete patches ( Fig. 11h). Peripheries of the rippled patches appear jagged on closer inspection. There are other kinds of patchy ripples where the rippled Facies A, B surfaces have been reworked in isolated patches by a second generation of ripples

Mat-protected ripples: These are ripples, which are surprisingly well preserved immediately below beds characterized by large-scale cross-strata or planar laminae of storm origin ( Fig. 11i). The sandstone is well sorted and there is no mud in between the rippled surface and the overlying cross-beds. There are Facies A, B also some examples where the ripples on top of a very thin sandstone bed can be traced into the immediately underlying bed (palimpsest ripples) 


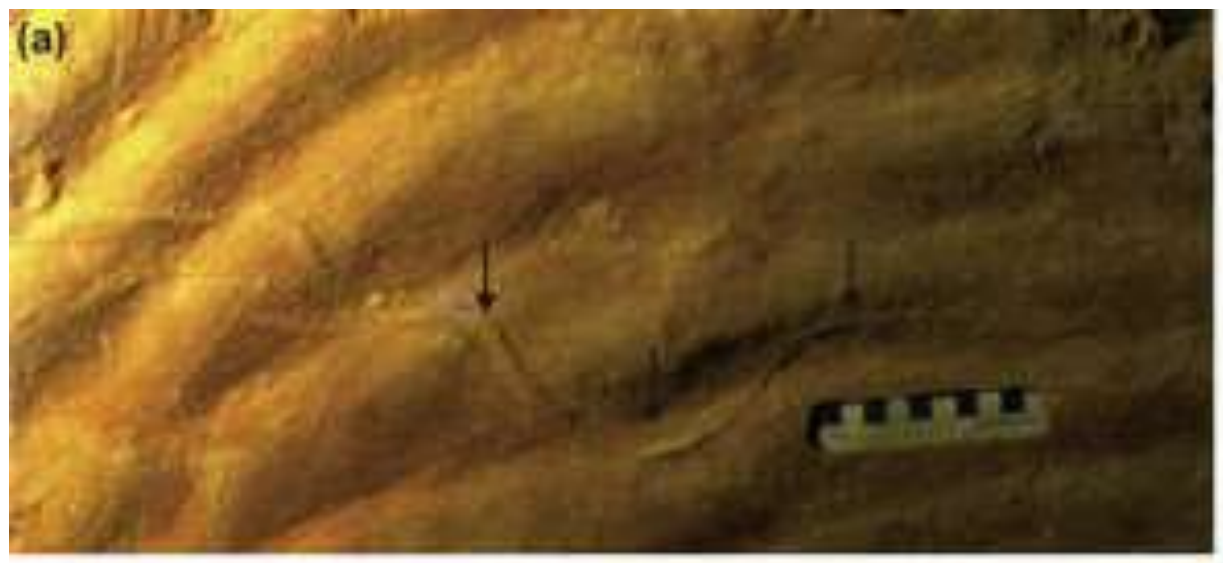

(b)
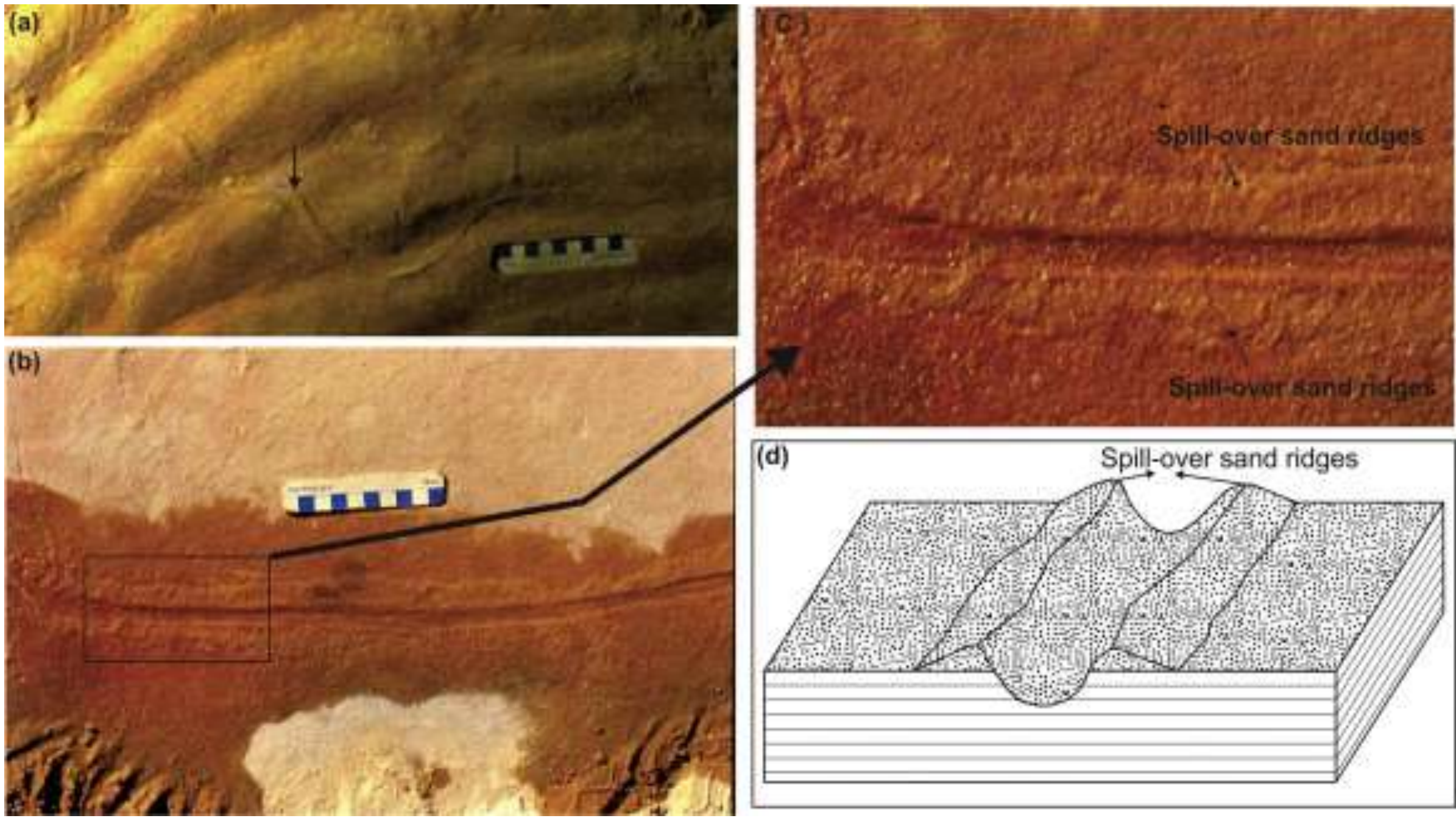

Fig. 2. The meandering groove type trace. Note the unequal width of the trail along its length

(black arrows), running across the rippled bed surface (a). Nearly straight parallel-sided groove with raised ridges on either side (b). A small portion of the trail (rectangular part in fig. a) has been highlighted showing spill-over sand ridges (black arrows) (c). Cartoon diagram showing detailed morphology of the trail, highlighting the spill-over sand ridges within it (d). 
These are linear grooves with meandering to rarely straight forms (Figs. 2a, b) and are characteristically of two different varieties. One group is characterized by very shallow and parallel-sided grooves (average width $4.1 \mathrm{~mm}$ ), with raised sand ridges on either side (Figs. 2b, c, d). These grooves are sometimes found in rippled surfaces across crests and troughs, being more pronounced on the troughs (Fig. 2a). In some other examples sand ridges occasionally show inhomogeneity in distribution, on either side, along the length of the groove, but clearly show segmentations (Figs. 2c, d). The ridge sandstone and the host sedimentary rocks are similar petrographically (Figs. 3a, b). In contrast, grooves of the second group are relatively long and devoid of any associated raised ridges, with undulatory lateral margins and occasional intact walls (Figs. 4a, b, c). These grooves are sometimes sinuous, self-crossing, forming loops (Fig. 4c) and distinctly cut the underlying laminae (Fig. 4b). Some grooves are of different shapes and sizes, nevertheless, the larger grooves often have flattened top along their lengths are branched (Fig. 4c). These grooves often contain a thin sediment layer over the bed surfaces (Fig. 4c). The measured width of these grooves varies from $2.5 \mathrm{~mm}$ to $4 \mathrm{~mm}$ within a single groove, whereas the average width for all such grooves is $3.2 \mathrm{~mm}$. Both varieties of linear grooves are commonly associated with wrinkle marks and shrinkage and/or desiccation cracks of microbial mat origin (Table 1; Figure 11).

Interpretation: Both kinds of grooves possibly represent trails of organisms (cf. Bottjer et al., 2000; Droser et al., 2002). They are distinctly different from abundantly present shrinkage and desiccation cracks (Harazim et al., 2013) by having much gentler side walls (not exceeding $12^{0}$ ) and U-shaped cross-sections, in contrast to V-shaped cross-sections of the desiccation cracks. The occurrence of the raised ridges points to a similarity to trilobite trails like Diplichnites 

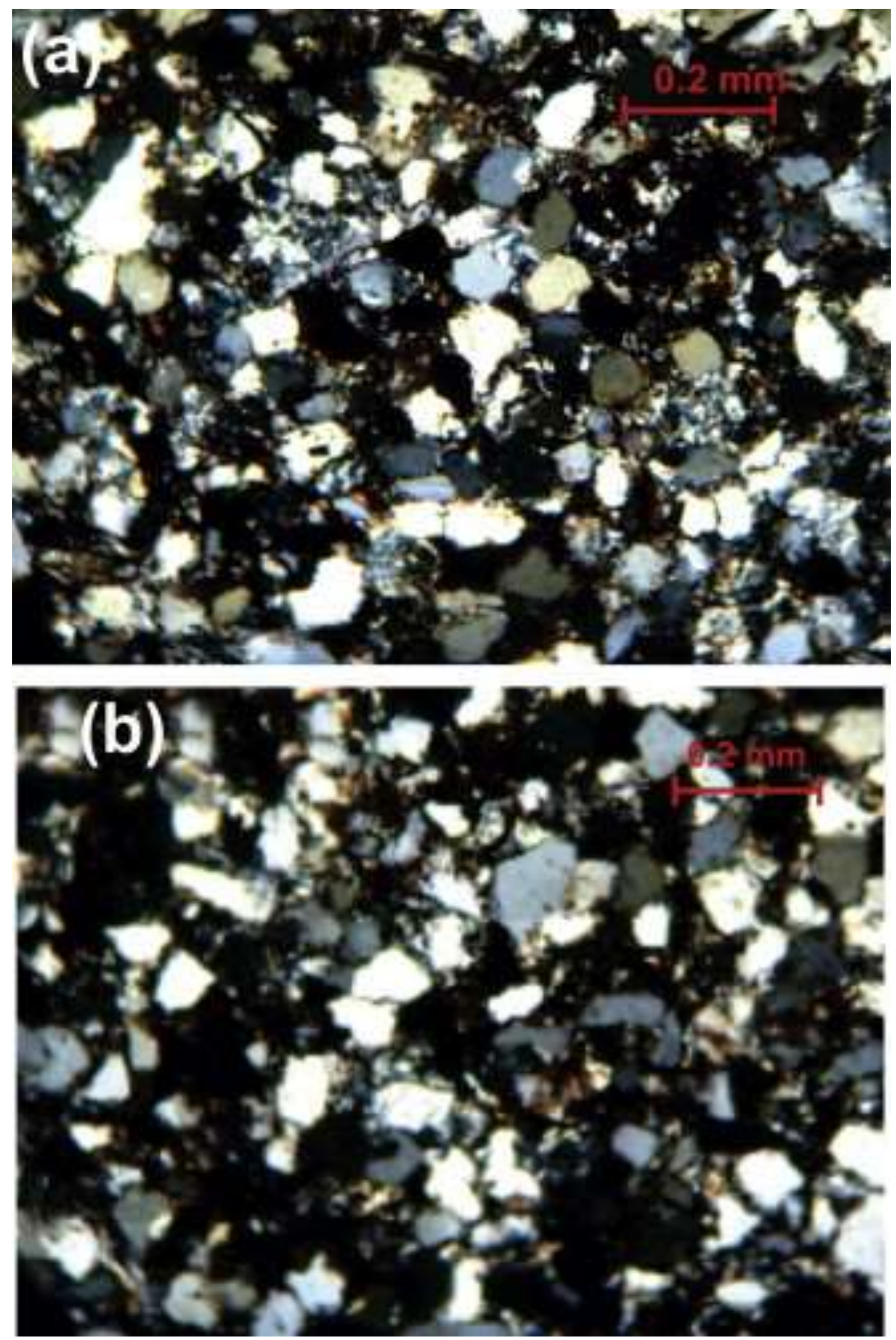

Fig. 3. Photomicrograph of the host sandstone bearing the trail of a possibly trilobite-like animal. Petrographically it is fine-grained quartz-arenite (a). Photomicrograph of the raised ridge of the same trail showing petrographic similarities with the host sandstone (b). 

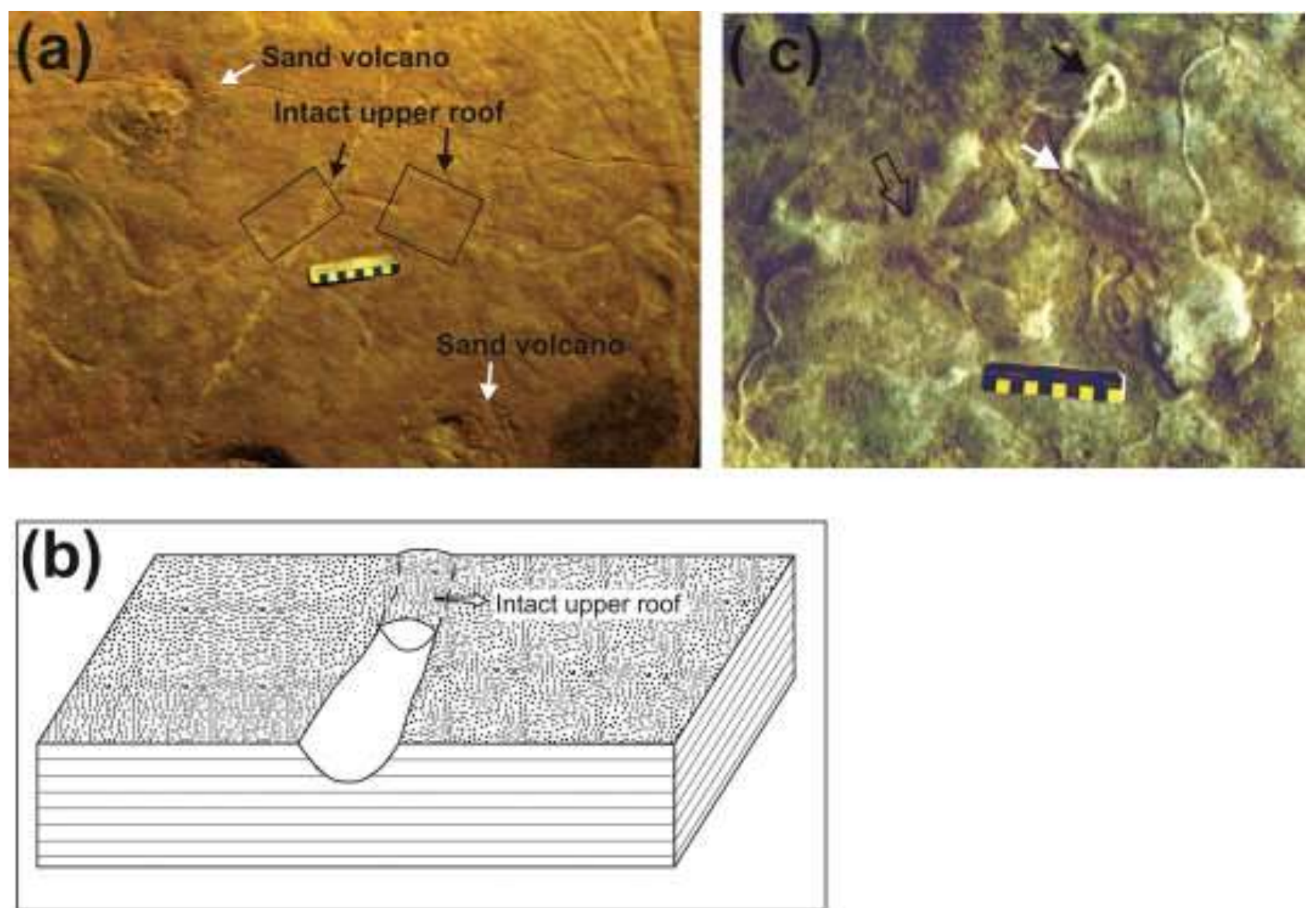

Fig. 4. The meandering groove type on a bedding surface showing intact upper wall sections, interpreted as trails of an annelid-like animal (black arrows). Note that the trail has no spill-over sand. Also note the associated sand volcanoes (white arrows) with central bulge and pit. The rectangles showing the areas where the upper roof of the burrow is intact (a). Cartoon diagram showing detailed morphology of the trail. Note that the trail clearly cut the underlying laminae. Note the intact upper wall of the burrow (b). Sinuous self-crossing burrow forming loops (black arrow) and tube-like in shape. Note that the upper wall is sometimes scratched-off so that the tubular shape becomes evident (white arrows) whereas the upper wall is intact in other parts of the burrow. Towards the left part the burrows are of different shapes and sizes with branches (open arrow). Also note that a thin mat layer covers the burrowed bed-surface and shape and size of the burrow may be modified as cohesive mat layers tend to flow by burial compaction and top part of the larger burrows become flattened. Scale length $10 \mathrm{~cm}(\mathrm{c})$. 
(Buatois and Mangano, 2011). The presence of spill-over sand clearly indicates that the organism pulled away the sand particles during its forward movement and probably had a sub-mat (semiinfaunal) lifestyle. The preservation of spill-over sand in such well sorted high-energy sandstone (Sarkar et al., 2008) is quite unlikely as one would normally expect sediment spill-overs in muddominated settings, as encountered from modern mud-dominated tidal flat environments by the authors (cf. Sarkar et al., 2011). The omnipresent microbial mats during the Proterozoic (cf. Schieber et al., 2007; and references therein) made sand cohesive and such a mat-infested substrate was possibly responsible for preserving the spill-over sand ridges in high energy sanddominated settings. Nonetheless, the observed inhomogeneous distribution of spill-over sand may be due to reworking by later currents/waves. The trails are found to be more pronounced in the troughs than the crests of the ripples; the obvious reason behind the fact is due to greater geomorphic protection from the later current/wave action. The changing width in the second kind of grooves, on the other hand, points towards the organism's capability to change their shapes, perhaps flattening and contracting their bodies, according to the need of locomotion on different kinds of bed topography, analogous possibly to annelid-type organisms. The larger inferred burrows often exhibit a flattened nature of their top, ascribed to burial compaction which will be more pronounced on the larger burrows as the cohesive mat layer tends to flow due to burial compaction (Fig. 4c). The organisms producing such trails are thus postulated to have possibly been deposit feeders (cf. Bailey et al., 2006). The presence of intact upper wall in places along the grooves suggests a sub-mat (infaunal) lifestyle during the extant mat-ground habitat. Overall, such delicate structures in sandstone likely owe their preservation to microbial mats that appear to have been present abundantly on the Sonia Sea floor (Samanta et al., 2011; Sarkar et al., 
2014). The close association of wrinkle marks and other microbial mat structures with the two types of grooves (inferred trails) supports this contention.

\subsection{Discoidal structures on bedding planes}

These are disc-shaped structures that resemble what is often called Precambrian medusae (Fig. 5a). The discs are nearly circular to elliptical in shape with maximum diameter of $21.6 \mathrm{~cm}$. The discs have negative relief, hence showing a peripheral ring with a central pit. Four to five (?) internal frond-like lobes are embedded in an apparently thin skin-like flap without any ornamented outer rim. The skin-like flap has wrinkle marks on top (Figs. 5b, c). The segmented lobes radiate from the central pit and merge with the peripheral ring although the fifth lobe is not so prominent (Figs. 5d, 6). In some field examples the internal segmentation and central pits are prominent but the wrinkled top is not common (Fig. 5d); the outer rim is always evident even after reworking (Fig. 5e). The interlobe angle varies from $60^{\circ}$ to $88^{0}$ (Fig. 5b). In some cases the central pit is prominent but the lobes are not so in some examples (Fig. 6; 5d). Energy Dispersive X-Ray Analysis, also known as EDX, EDS or EDAX has been used to understand the elemental composition of the materials. EDS are usually the attachments systems to the Scanning Electron Microscope (SEM) from where the specimen of interest identified by the imaging capability of the latter. Surficial elemental mapping also be possible by this technique. Such analysis of the sedimentary rocks bearing the trace of the discs finds a significant carbon concentration (Fig. 7).

Presence of pyrite is also evident from the thin section of the host sedimentary rock (Fig. 8). 

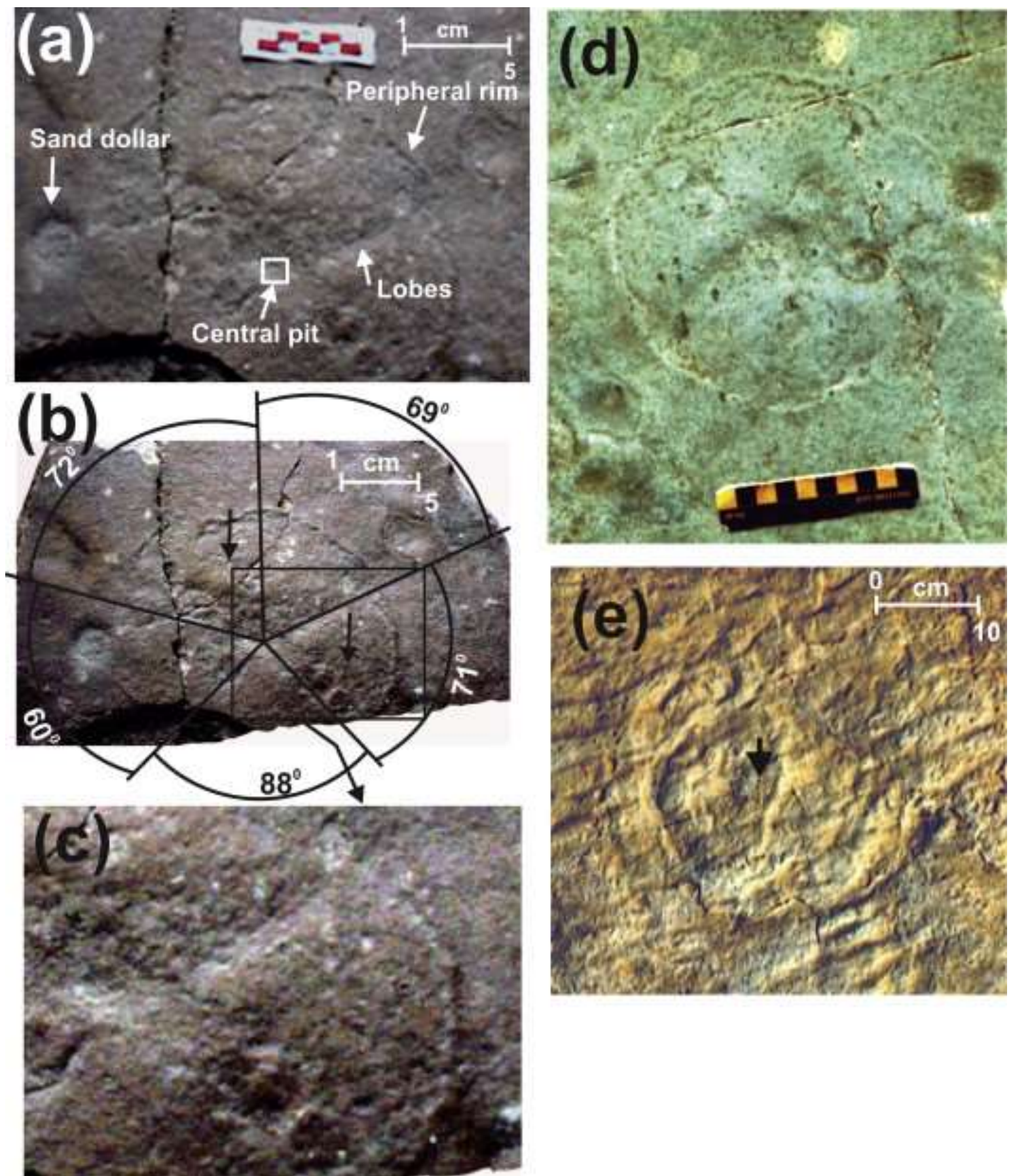

Fig. 5. The near-circular to elliptical discoidal trace of an unknown organism, with negative relief and showing a central pit (arrow) and frond-like lobes emerging from the central pit that merge with the peripheral ring (a). The discoidal trace showing five (?) internal lobes. Note the inter-lobe angle varies from 600 to 880 . Also note the skin-like wrinkled flap, marked by a rectangular area (b), which has been highlighted below (c). Field examples of the discoidal structures. Note that the central pit and the outer rim are prominent, without wrinkled skin-like flap (d). The discoidal structure reworked by a wave-rippled bed overlying it where the outer rim of the structure was not planed-off thus producing a palimpsest structure (cf. Sarkar et al., 2008). Note the central pit (arrow) (e). 


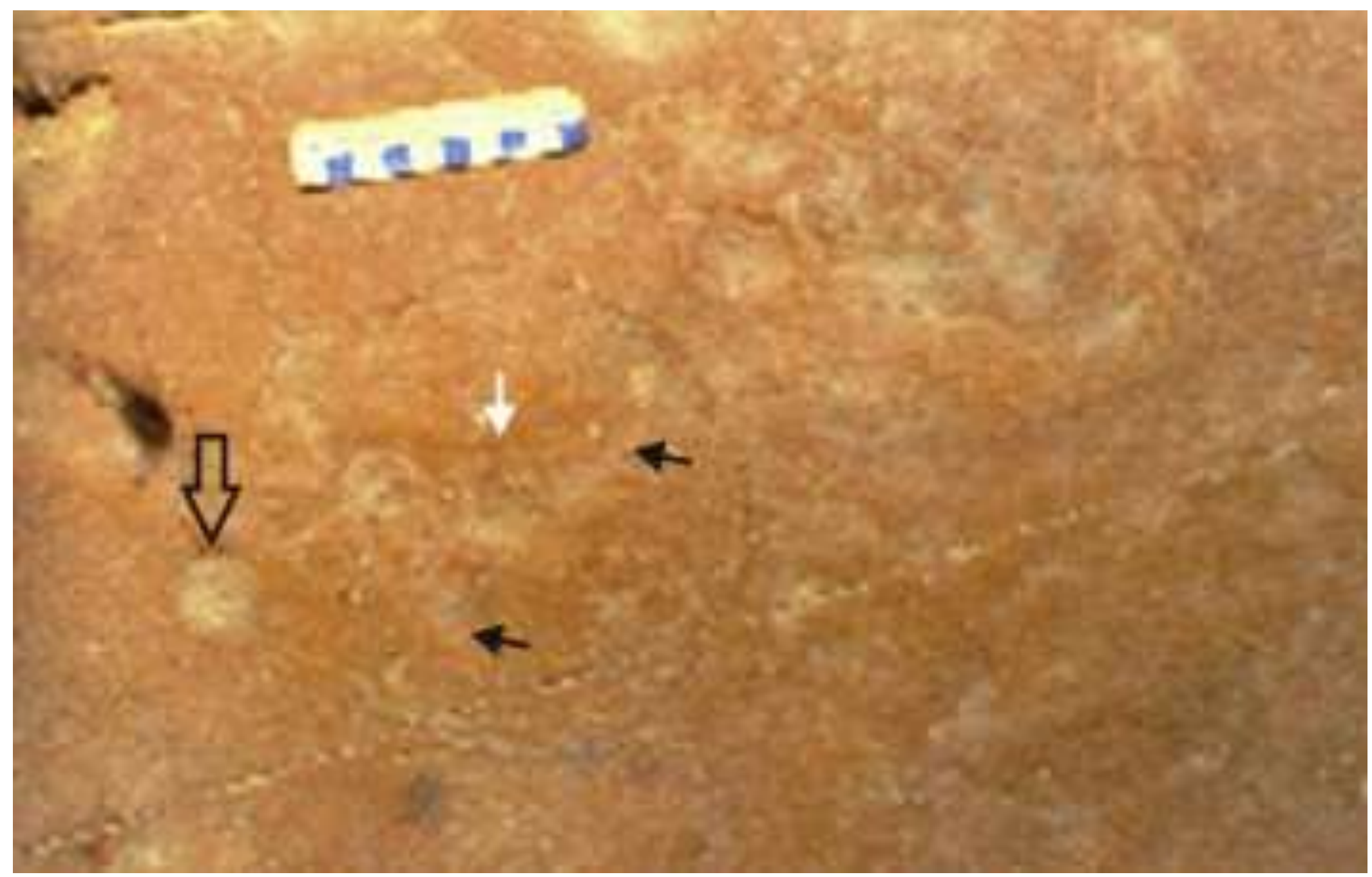

Fig. 6. In-situ example of near-circular to elliptical trace of discoidal structure where the central pit (solid white arrow) is prominent but the lobes (solid black arrows) are faintly preserved. Note that the example is associated with sand dollar-like features (open arrow) shown in fig. 9. 

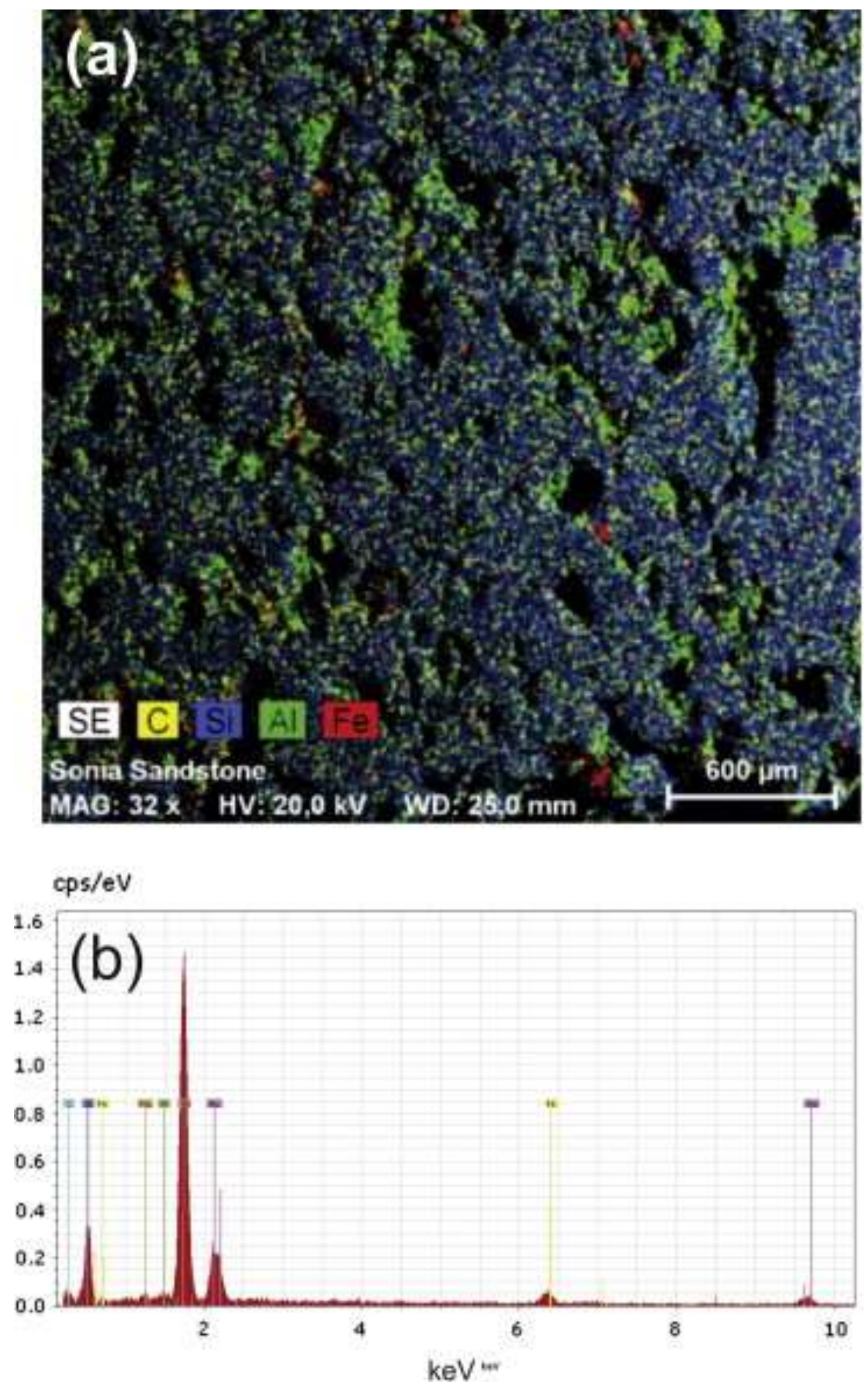

Fig. 7. Surface elemental map showing distribution of carbon within the discoidal feature (rectangular area marked in fig. 5a) (a). The concentration of carbon (C) content at the central part of the discoidal structure, determined from EDAX analysis, is shown (b). 


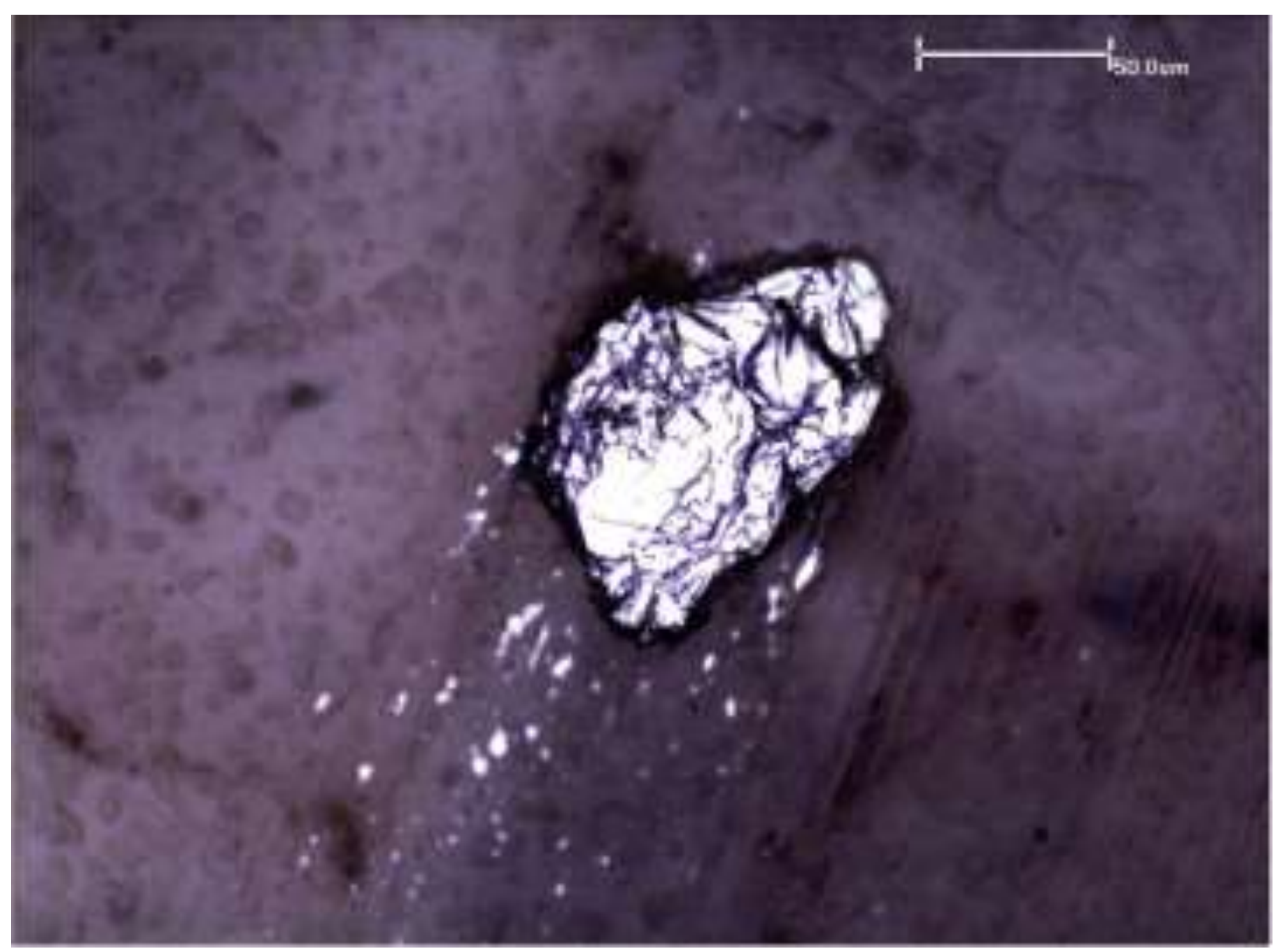

Fig. 8. Photomicrograph under reflected light showing pyrite concentration within the host sediments containing the discoidal trace. The pyrites are thought to have formed due to decomposition of organic materials. 
In addition, some circular flattened structures without any internal segmentation but with internal symmetry, often found in clusters, with negative relief, and of much smaller dimensions, are also associated locally with the larger discs (Fig. 9).

Interpretation: These discoidal structures are different from those of microbial mat stabilized sand volcanoes that are present abundantly on the bedding planes (Sarkar et al., 2006; 2008), as the sand volcanoes have positive relief; they also have no internal segmentation. The crosssection of the sample containing the trace lacks any 'sand-plug' below the central pit as expected in the case of a sand volcano interpretation (Fig. 10). The discoidal impressions are likely to be organic, postulated from the repeated occurrence and internal symmetry of the structures. Moreover, no known physical process can create such structures. Although there is no evidence for the existence of an organism bearing hard parts during the Proterozoic, the negative impressions are possibly significant. The negative impression may invoke the possibility of an organism with enough weight to produce such an impression, compared to other soft bodied and Ediacaran organisms. The cohesive mat-infested substrate, being thixotropic could have produced such negative impressions in response to weight of the organisms. The impressions are postulated to be the resting traces of some epibenthic soft/hard bodied organisms that may have been the progenitors of some organisms of unknown affinity; or they may possibly have been related to the cnidarians as reported from rocks of equivalent age from the White Mountains in California (Dornbos and Bottjer, 2000), notwithstanding the recent example documented by Kumar et al. (2012) from the Jodhpur Group that closely resembles shrinkage cracks (cf. Harazim et al., 2013). The possible evidence for segmented body morphology further corroborates the contention. The difference in angular variation between the interlobe angles 


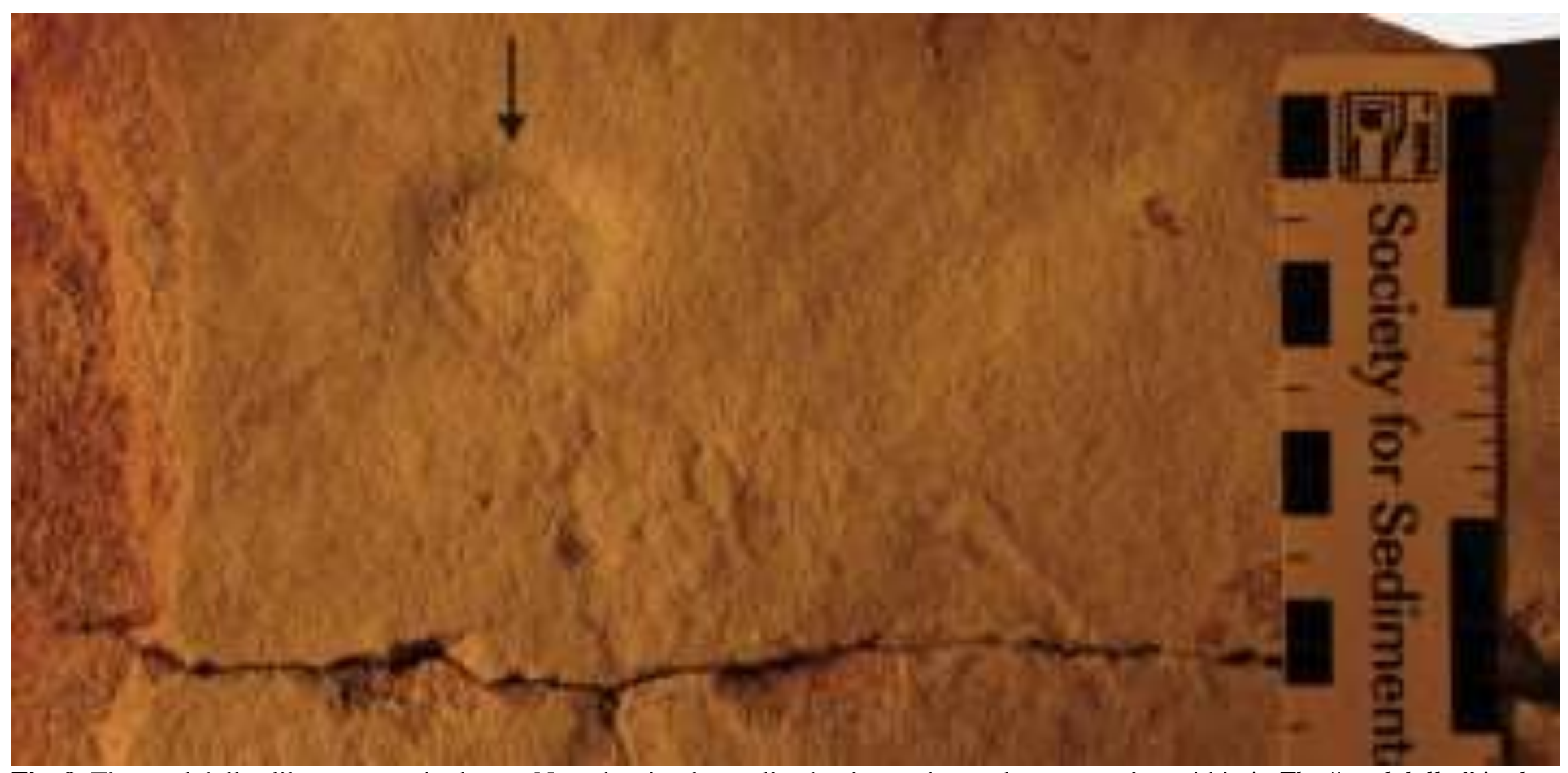

Fig. 9. The sand dollar-like structure is shown. Note the circular outline having no internal segmentation within it. The "sand dollar" is also found closely associated with the larger discoidal structures as shown in fig. 5a (arrow). 


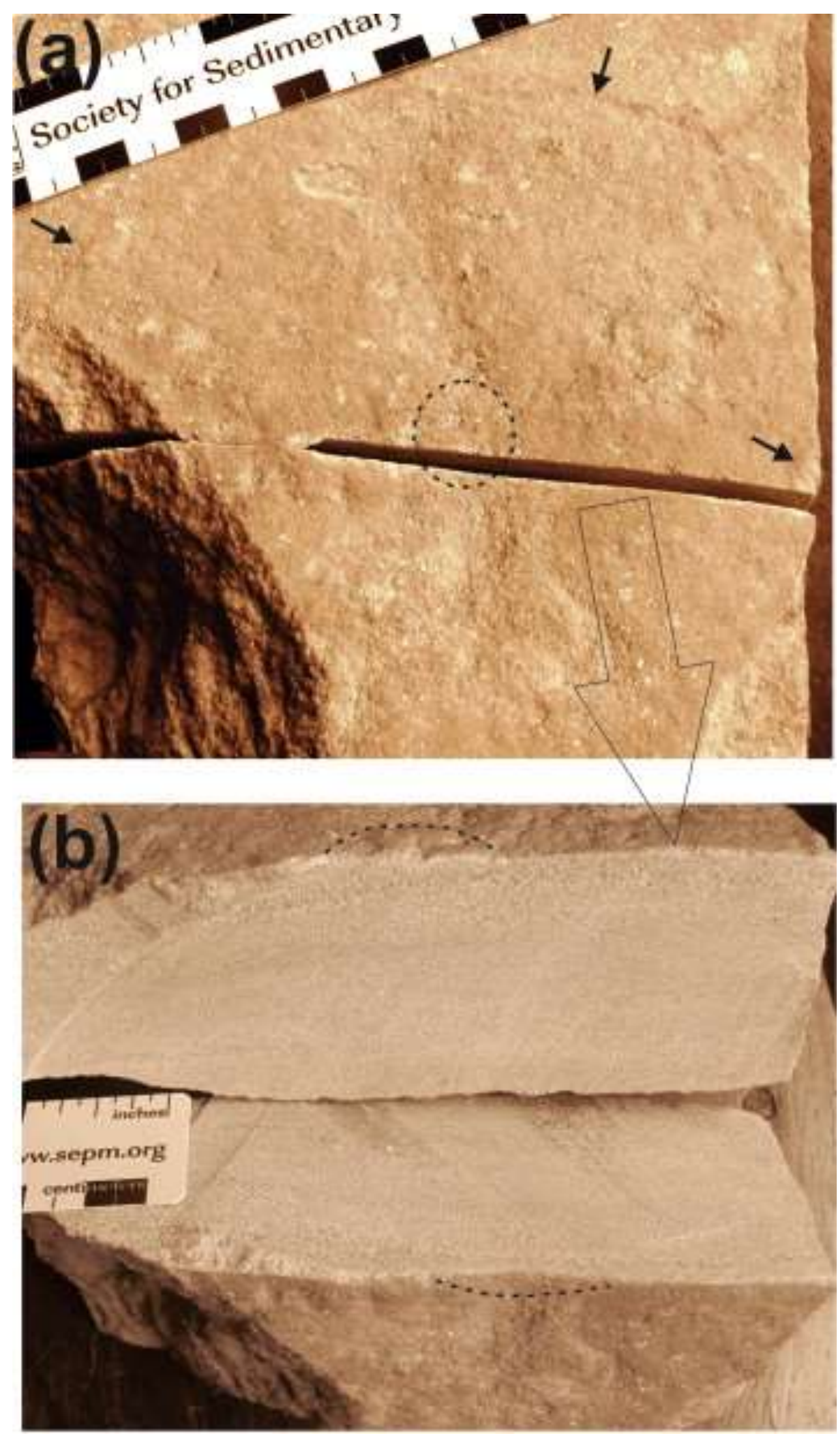

Fig. 10. The discoidal structure with central pit (encircled by dotted line) and outer rim (black arrows) (a). Oblique view of the bed-normal section of the discoidal structure. Note the vertical section without any sand-plug and lamina disruption (b). 
may be due to deformation and diagenetic modification. The skin-like outer surface with wrinkle marks probably represents the outer ornamented body impression of the organism. Microbial mat colonies produce various kinds of medusoid forms (e.g., Banerjee et al., 2010; Sarkar et al., 2014 and references therein) that are often misinterpreted as Ediacara fossils. These traces may also be related to a microbial mat colony, but the internal lobes are quite unusual for any possible microbial mat interpretation. Hence, an on-mat benthic life-style can be postulated. The pyrite and carbon concentration within the host sedimentary rocks may be due to biogenic decomposition of organic materials (Samanta et al., 2011).

The observed smaller circular impressions resemble sand dollars of modern marine environments, particularly in external appearance. The remarkable similarities in morphology among these impressions and their repetitive occurrence at different stratigraphic levels points towards an organic origin. From their close association with the larger disc-like impressions, a similar on-mat benthic life style can be postulated for these postulated "organisms" also.

\section{Discussion}

The Ediacara and other soft-bodied organisms dominated the late Proterozoic biosphere in a matground substrate condition (Bottjer et al., 2000). The dominance of microbial mats may have influenced local oxygen levels allowing benthic organisms to thrive, and the decomposing mats may have supplied nutrients for the organisms. The presence of inferred bioturbations, seen from the field evidence to have been essentially horizontal (Figs. 2, 4), as described above, may suggest that biograzers which were omnipresent in the Cambrian and beyond, possibly originated in the latest Proterozoic settings. The preservation of microbial mat structures is generally 

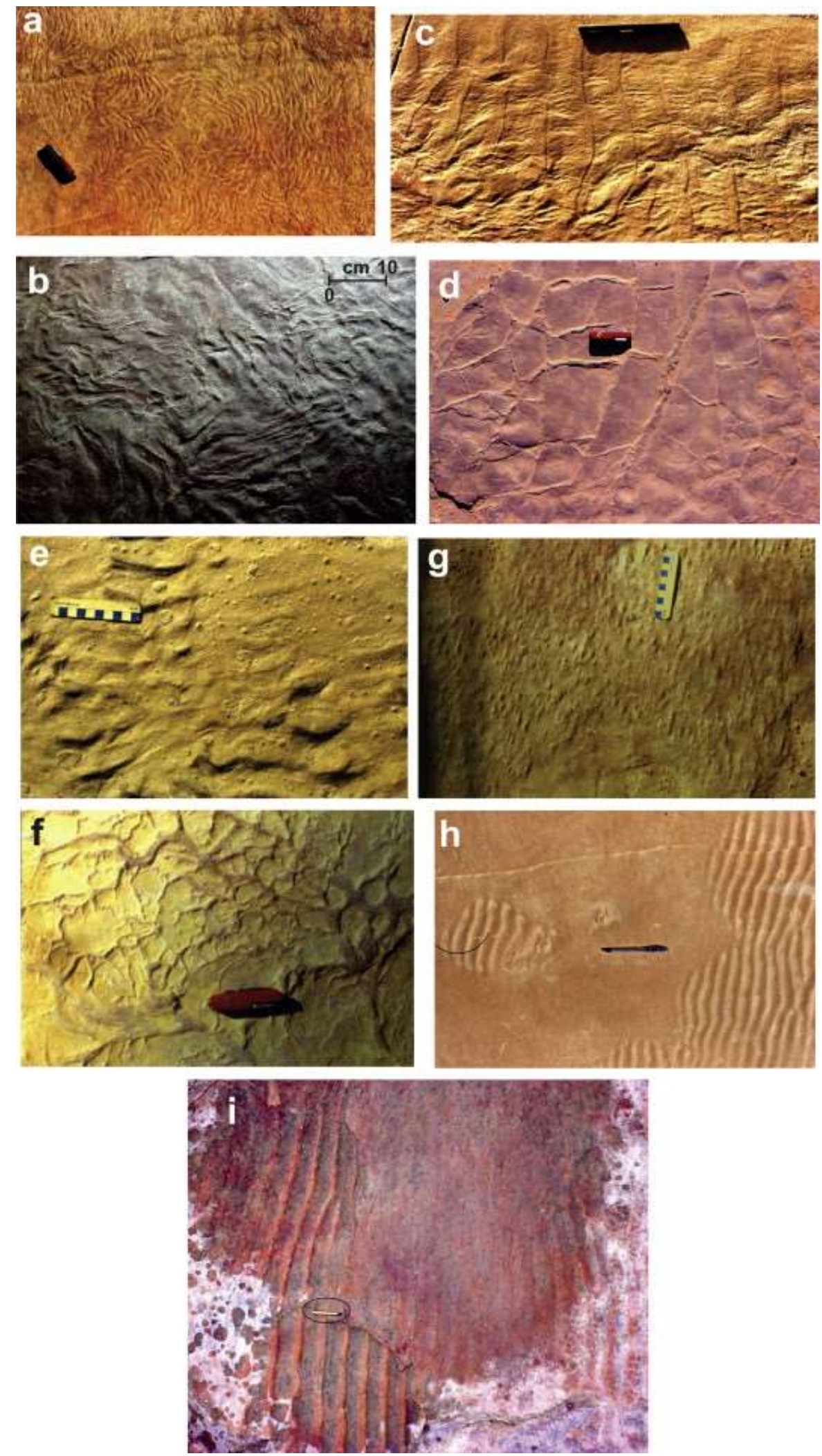

Figure 11. Microbial mat structures. Discoidal mat colony. Knife length $7.5 \mathrm{~cm}$. (a). Crumpled mat layer (b). Wrinkle structures. Pen length $15 \mathrm{~cm}$ (c). Mat-induced cracks. Knife length $7.5 \mathrm{~cm}(\mathrm{~d})$. Sand bulges. Scale length $10 \mathrm{~cm}$ (e). Mat-induced ridges (petee). Knife length $7.5 \mathrm{~cm}$ (f). Setulfs structures. Scale length $10 \mathrm{~cm}(\mathrm{~g})$. Mat-protected patchy ripples. Pen length $14 \mathrm{~cm}$ (h). Palimpsest ripples. Matchstick (marked by an ellipse) length $2.5 \mathrm{~cm}$ (i). 
inversely related to the biograzers. Such an example has been established by Buatois et al. (2013). Abundant preservation of microbially induced sedimentary structures is coincident with the disappearance of trace and body fossils in the Argentinean deposits of the PermoCarboniferous succession (Buatois et al., 2013). In such cases the disappearance of trace fossils is exclusively related to vertical bioturbation (Buatois et al., 2013), that is apparently absent in the Neoproterozoic. Nevertheless, dense bioturbation fabrics within sediments of ca. $555 \mathrm{Ma}$ age, the preserved depth of which reached up to $5 \mathrm{~cm}$, have been discovered from the Ediacaran Khatyspyt Formation of the northern Siberian Platform (Rogov et al., 2012). The ichnotaxon itself is attributed to the meniscate ichnogenus Nenoxites (Rogov et al., 2012; 2013). However, reliable Ediacaran trace fossils of relatively simple horizontal burrows and trails from shallowwater deposits are mostly younger than $560 \mathrm{Ma}$ (Liu et al., 2010). There is a possibility then that the Sonia trace fossil assemblage might have preceded the aforementioned assemblages even by a short margin. Nevertheless, to impart adequate certitude to such a claim needs precise age constraint that is generally lacking in the said examples. Keeping in view, nonetheless, the bioturbations of the Sonia Sandstone are significant in providing the evolutionary pathways of early life.

The straight to sinuous Sonia trails with raised ridges are interpreted to represent horizontal burrows of annelid-type organisms, of sub-mat life-style, similar to the burrows described by Gingrass et al. (2011a), having no connection with the sediment-water interface as they apparently occurred below the mat layer (cf. undermat miner, Seilacher, 1999). These postulated undermat miners (Seilacher, 1999) were likely to have been oxygen-hunters and moved from one place to another in search of oxygen during feeding from the decomposed microbial mats. Analogous trails (Taphrhelminthopsis) are also described from the Poleta 
Formation, California of the early Cambrian age (Hagadorn et al., 2000). Thus it is evident that horizontal burrowing organisms characterized the Neoproterozoic and the early Cambrian (cf. Bottjer et al., 2000; Hagadorn et al., 2000). In the second kind of trail detailed in the Sonia Sandstone there is a similarity with trilobite trails such as Diplichnites, and this clearly suggests that the organisms were on-mat grazers (cf. Gingrass et al., 2011a). These traces have close resemblance to burrows formed at the sediment-water interface (cf. Gingrass et al., 2011b). Triloblastic organisms probably originated during the Neoproterozic (Rogov et al., 2012; 2013), however, an alternative assertion is that they may be mycetozoan plasmodia (Gámez Vintaned and Zhuravlev, 2013). After the "Cambrian explosion" the true bioturbators developed and homogenized the sediments by making vertical burrows (Bottjer et al., 2000). As the Neoproterozoic shelf was largely covered by microbial mats the sediment-water interface was possibly anoxic/sulphidic (Bailey et al., 2006). The abundant preservation of pyrites associated with the described trace-bearing sedimentary rocks (Fig. 8) corroborates the connotation.

The disc-like structures may be comparable with Ediacaran species such as Nimbia occlusa and another type morph Aspidella terranovica (cf. Meert et al., 2011). Nimbia has been reported from Ediacaran localities such as the Krol-Tal Belt (India), West Africa, the Flinders Ranges (Australia), the Great Basin (Western U.S.A.), the Digermul Peninsula (Norway), the Avalonian blocks of Newfoundland and the White Sea Region (Russia) (Hofmann et al., 1990; Crimes et al., 1995; Crimes and McIlroy, 1999; Gehling et al., 2000; Fedonkin, 2003; Shanker et al., 2004; Bertrand-Sarfati et al., 1995; Meert et al., 2011). However the segmentation that is found in the Sonia structures is absent in Nimbia occlusa. Aspidella terranovica has been described from the Podolia, Ukraine, the Ural Mountains, NW Canada, the Avalon Peninsula, Newfoundland, Namibia and Kazakhstan (Gehling et al., 2000; Meert et al., 2011). The structure 
of the Sonia Sandstone is dissimilar to Aspidella terranovica in many aspects. The Sonia structure lacks any outer ornamented rim and contains radiating lobes emerging from the central pit, as compared to Aspidella terranovica. Brooksella canyonensis, is another important lobate trace fossil and may be comparable with the Sonia traces. But in Brooksella canyonensis the inter-lobe ridges have high relief that separated distinctly each lobe from the others and are detached from each other along with up-curving (concave-up) lobe surface, dissimilar in many aspects to the Sonia traces (Kauffman and Fursich, 1983; Schopf and Klein, 1992). Thus this Sonia structure is quite different in detailed morphology from that of other similar-looking Ediacaran examples described in the literature. The inferred body impressions possibly represent the resting place of an organism that was a suspension feeder in matground habitat and likely had an on-mat lifestyle. The finding of carbon concentrations on the sedimentary rock surface of the soft/hard bodied impression by surface elemental mapping supports its possible organic origin (Fig. 7).

The effects of substrate condition on the evolution of early life has been a matter of discussion during the last two to three decades and the advent of multicellular organisms has been variously termed as an 'agronomic revolution' (Seilacher and Pflüger, 1994) or the 'substrate revolution' (Bottjer et al., 2000). The nature of the substrate might have been significant in evolutionary pathways as it has pronounced effects on benthic palaeoecology and palaeohabitat (Brasier, 1992; Brasier et al., 1994; Seilacher and Pflüger, 1994; Hagadorn and Bottjer, 1999; Seilacher, 1999; Bottjer et al., 2000; Dornbos and Bottjer, 2000; Droser et al., 2002; Dornbos et al., 2004; Jensen et al., 2005; Droser et al., 2006). The ocean sediment chemistry may also have been different during the Precambrian (Brasier, 1992; Seilacher and Pflüger, 1994; Gehling, 1999; McIlroy and Logan, 1999; Shields, 1999; Bailey et al., 2006). The 
microbial mats possibly played a significant role in supplying the oxygen and nutrients for the early evolution of more complex life. More importantly the mats were significant for supplying oxygen rather than food (Gingrass et al., 2011a). Oxygen-hunting appears to be the driving force behind the locomotion of these organisms. Large motile metazoan animals have been recorded from deep-water environments at Mistaken Point, southeastern Newfoundland, Canada (Liu et al., 2010). The presence of postulated on-mat and sub-mat organisms in the Sonia Sea floor possibly further strengthens the idea that, along with a bottom-hugging life-style (notwithstanding a temporary sulphidic condition) the sub-mat benthic life-styles (hypoxiatolerant physiology) also originated during this Ediacaran Period, as against the Lower Palaeozoic onset postulated by Gingrass et al. (2011a). The question thus tentatively arises from the present discussion, whether the precursors of annelids and Cnidarians date back to the Latest Proterozoic. It is pertinent that the observed Neoproterozoic bioturbation is largely attributed to the oxygen-hunting of the oxygen-dependent early marine metazoans and this clue possibly provides an important tool in evaluating evolution of early more complex life.

\section{Conclusions}

The suspected body impressions and the inferred burrow-like trails that are found in the ca. 600 Ma Sonia Sandstone are likely to have had a biogenic origin as no known physical process can explain the origin of such features. The microbial mat affinities of these features are also unable to explain the origin of such impressions. The body impressions possibly represent resting marks of an organism of unknown affinity; however, speculatively, they possibly resembled cnidarians and the elongated trails, equally speculatively, resemble burrows of what might have been some 
early annelid-types of organisms. All the traces are closely associated with microbial mat features that are abundant and profuse in the Sonia Sandstone. Microbial mats possibly provided the oxygen and food for these organisms and probably played a significant role in preserving such delicate features in sandy siliciclastic rocks. The substrate condition plays a significant role in the evolution of the early bioturbators. The occurrence of such bioturbations supports speculation that the progenitors of cnidarians, and annelid kinds of organisms possibly originated during the late Proterozoic. The sub-mat benthic lifestyle also possibly originated during the late Proterozoic, in contrast to the early Palaeozoic age for their onset, postulated by some authors.

Acknowledgements: PS gratefully acknowledges the financial support received from DST Fast track project (Young Scientist Scheme, No: SR/FTP/ES-03/2011). PS, SM and SS acknowledge their respective Departments for the infrastructural help. SS also acknowledges financial help from CAS (Phase V), UPE-II programme of Jadavpur University. PGE thanks the National Research Foundation and University of Pretoria, South Africa, for financial support. The authors are thankful to two anonymous reviewers for their valuable comments and suggestions.

\section{References}

Albani, A., Bengtson, S., Canfield, D., Bekker, A., Macchiarelli, R., Mazurier, A., Hammarlund, E., Boulvais, P., Dupuy, J., Fontaine, C., Fürsich, F., Gauthier-Lafaye, F., Janvier, P., Javaux, E., Ossa, F., Pierson-Wickmann, A., Riboulleau, A., Sardini, P., Vachard, D., Whitehouse, M., Meunier, A., 2010. Large colonial organisms with coordinated growth in oxygenated environments 2.1 Gyr ago. Nature, 466, $100-104$. 
Bailey, J.V., Corsetti, F.A., Bottjer, D.J., Marenco, K.N., 2006. Microbially-mediated environmental influences on Metazoan colonization of Matground ecosystems: Evidence from the lower Cambrian Harkless Formation. Palaios, 21, 215 - 226.

Balakrishna, T.S. 1980. Compiled bouguer anomaly map of northern India. ONGC report.

Banerjee, S., Sarkar, S., Eriksson, P.G., Samanta, P., 2010. Microbially related structures in siliciclastic resembling Ediacaran fossils: Examples from India, modern and ancient, In: Seckbach, J. and Oren, A. (eds.), Microbial Mats: Modern and Ancient Microorganisms in Stratified Systems, Springer-Verlag, pp. $109-129$.

Bertrand-Sarfati, J., Moussine-Pouchkine, A., Amard, B., Ait Kaci Ahmed, A., 1995. First Ediacaran fauna found in Western Africa and evidence for an early Cambrian glaciations. Geology, 23, $133-136$.

Bottjer, D.J., Hagadorn, J.W., Dornbos, S.Q, 2000. The Cambrian substrate revolution: GSA Today, $10,1-7$.

Brain, C.K.B., Prave, A.R., Hoffmann, K.H., Fallick, A.E., Botha, A., Herd, D.A., Sturrock, C., Young, I., Condon, D.J., Allison, S.G., 2012. The first animals: ca. 760-million-year-old sponge-like fossils from Namibia. South African Journal of Science, 108, 1 - 8.

Brasier, M., Cowie, J., Taylor, M., 1994. Decision on the Precambrian-Cambrian boundary stratotype. Episodes, 17, 3 - 8 .

Brasier, M.D., 1992. Background to the Cambrian explosion. Journal of the Geological Society, London, 149, 585 - 587.

Buatois, L., Mangano, M.G., 2011. Ichnology; Organism-Substrate interactions in space and time. University Press, Cambridge, p. 347. 
Buatois, L. A. Netto, R. G., Mangano, M. G., Carmona, N. B., 2013. Global deglaciation and the re-appearance of microbial matground-dominated ecosystems in the late Paleozoic of Gondwana. Geobiology, 11 (4), 307 - 317. DOI: 10.1111/gbi.12038.

Chauhan, D.S., 1999. Tectonic and sedimentary evolution of the Marwar basin: A Neoproterozoic-Early Cambrian intracratonic sag basin. In: Kataria, P. (ed.) Proceedings of the seminar on Geology of Rajasthan-status and perspective (A. B. Roy Felicitation Volume) Geology Department, MLSU, Udaipur, pp. 111 - 125.

Crimes, T.P., Insole, A., Williams, B.J.P., 1995. A rigid bodied ediacaran biota from Upper Cambrian strata in Co. Wexford, Eire. Geological Journal, 30, 89 - 109.

Crimes, T.P., Mcllroy, D., 1999. A biota of Ediacaran aspect from lower Cambrian strata on the Digermul Peninsula, Arctic Norway. Geological Magazine, 136, 633 - 642.

Dornbos, S.Q., Bottjer, D.J., 2000. Evolutionary palaeoecology of the earliest echinoderm: Helicoplacoids and the Cambrian substrate evolution. Geology, 28, 839 - 842.

Dornbos, S.Q., Bottjer, D.J., Chen, J.Y., 2004. Evidence for seafloor microbial mats and associated metazoan lifestyles in Lower Cambrian phosphorites of Southwest China. Lethaia, 37, $127-137$.

Droser, M.L., Gehling, J.G., Jensen, S.R., 2006. Assemblage palaeoecology of the Ediacara biota: The unabridged edition? Palaeogeography Palaeoclimatology Palaeoecology, 232, $131-147$.

Droser, M.L., Jensen, S., Gehling, J.G., 2002. Trace fossils and substrates of the terminal Proterozoic - Cambrian transition: implications for the record of early bilaterians and sediment mixing. Proceedings of the National Academy of Sciences of the United States of America, 99, 12572 - 12576. 
Eriksson, P.G., Sarkar, S., Banerjee, S., Porada, H., Catuneanu, O., Samanta, P., 2010. Paleoenvironmental context of microbial mat-related structures in siliciclastic rocks: Examples from the Proterozoic of India and South Africa. In: Seckbach, J., Oren, A. (eds.), Microbial Mats: Modern and Ancient Microorganisms in Stratified Systems, Springer-Verlag, pp. $73-108$.

Fedonkin, M.A., 2003. The origin of the Metazoa in the light of the Proterozoic fossil record. Paleontological Research, 7, $9-41$.

Friedman, G.M., Sanders, J.E., 1974. Positive-relief bedforms on modern tidal-flat that resemble molds of flutes and grooves: implications for geopetal criteria and for origin and classification of bedforms. Journal of Sedimentary Petrology, 44, $181-189$.

Gehling, J.G., 1999. Microbial mats in terminal Proterozoic siliciclastics: Ediacaran death masks. Palaios 14, $40-57$.

Gehling, J.G., Narbonne, G.M., Anderson, M.M., 2000. The first named Ediacaran body fossil; Aspidella terranovica. Palaeontology, 43 (Pt. 3), 427 - 456.

Gerdes, G., Klenke, T., Noffke, N., 2000. Microbial signatures in peritidal siliciclastic sediments: a catalogue. Sedimentology, 47, $279-308$.

Gingras, M., Hagadorn, J.W., Seilacher, A., Lalonde, S.V., Pecoits, E., Petrash, D., Konhauser, K.O., 2011a. Possible evolution of mobile animals in association with microbial mats. Nature Geoscience Letter, 4, 372 - 375 .

Gingras, M.K., Waldron, J.W.F., White, C.E., Barr, S.M., 2011b. The evolutionary significance of a Lower Cambrian trace-fossil assemblage from the Meguma terrane, Nova Scotia. Canadian Journal of Earth Science, 48, $71-85$. 
Gámez Vintaned, J.A., Zhuravlev, A.Yu., 2013. The oldest evidence of bioturbation on Earth: Comment. Geology, e299, doi:10.1130/G34085C.1.

Hagadorn, J.W., Bottjer, D.J., 1999. Restriction of a characteristic late Neoproterozoic biotope: suspect microbial structures and trace fossils at the Vendian-Cambrian transition. Palaios, $14,73-85$.

Hagadorn, J.W., Fedo, C.M., Waggoner, B., 2000. Early Cambrian Ediacaran-type fossils from California. Journal of Paleontology, 74, 731 - 740.

Harazim, D., Callow, R.H.T., Mcilroy, D., 2013. Microbial mats implicated in the generation of intrastratal shrinkage ('synaresis') cracks. Sedimentology, 60, 1621 - 1638 IAS, doi: $10.1111 /$ sed. 12044

Hill, P.R., Meule, S., Longuepee, H., 2003. Combined-flow processes and sedimentary structures on the shore face of the wave-dominated Grande-riviere-de-la-Baleine delta. Journal of Sedimentary Research, 73 (2), 217 - 226.

Hofmann H.J., Mountjoy E.W., 2001. Namacalathus-Cloudina assemblage in Neoproterozoic Miette Group (Byng Formation), British Columbia: Canada's oldest shelly fossils. Geology, 29, $1091-94$.

Hofmann, H.J., Narbonne, G.M., Aitken, J.D., 1990. Ediacaran remains from intertillite beds in northwestern Canada. Geology, 18, 1199 - 1202.

Jensen, S., Droser, M.L., Gehling, J.G., 2005. Trace fossil preservation and the early evolution of animals. Palaeogeography Palaeoclimatology Palaeoecology, 220, $19-29$.

Kauffman, E.G., Fursich, F., 1983. Brooksella canyonensis: a billion year old complex metazoan trace fossil from the Grand Canyon. Geological Society of America, Abstracts with Programs, 15, p. 608. 
Knoll, A.H., Carroll, S.B., 1999. Early animal evolution: emerging views from comparative biology and geology. Science, 284, $2129-2137$.

Knoll, A.H., Walter, M.R., Narbonne, G.M., Christie-Blick, N., 2004. A new period for the Geologic time scale. Science, 305, $621-622$.

Kumar, S., Pandey, S.K., 2008. Discovery of trilobite trace fossils from the Nagaur Sandstone, the Marwar Supergroup, Dulmera area, Bikaner District, Rajasthan. Current Science, 94 (8), $1081-1085$.

Kumar, S., Srivastava, D.K., Ahmad, S., 2012. Five-armed body fossil from the Ediacaran Jodhpur Sandstone, Marwar Supergroup, western Rajasthan, India: a possible precursor of phylum Echinodermata. Current Science, 102 (1), $24-26$.

Liu, A.G., Mcllroy, D., Brasier, M.D., 2010. First evidence for locomotion in the Ediacara biota from the 565 Ma MistakenPoint Formation, Newfoundland. Geology, 38, 123 - 126.

Malone, S.J., Meert, J.G., Banerjee, D.M., Pandit, M.K., Tamrat, E., Kamenov, G.D., Pradhan, V.R., Sohl, L.E., 2008. Paleomagnetism and Detrital Zircon Geochronology of the Upper Vindhyan Sequence, Son Valley and Rajasthan, India: A ca. 1000 Ma age for the Purana Basins? Precambrian Research, 164, $137-159$.

Martin, M.W., Grazhdankin, D.V., Bowring, S.A., Evans, D.A.D., Fedonkin, M.A., Kirschvink, J.L., 2000. Age of bilaterian body and trace fossils, White Sea Russia: implications for metazoan evolution. Science, 288, $841-845$.

McIlroy, D., Logan, G.A., 1999. The impact of bioturbation on infaunal ecology and evolution during the Proterozoic - Cambrian transition. Palaios, 14, 58 - 72. 
Meert, J.G., Gibsher, A.S., Levashova, N.M., Grice, W.C., Kamenov, G.D., Ryabinin, A.B., 2011. Glaciation and 770 Ma Ediacara (?) Fossils from the Lesser Karatau Microcontinent, Kazakhstan. Gondwana Research, 19, $867-880$.

Narbonne, G.M., 2005. The Ediacara Biota: Neoproterozoic Origin of Animals and their Ecosystems. Annual Review Earth Planetary Science, 33, 421 - 442.

Noffke, N., Gerdes, G., Klenke, T., Krumbein, W.E., 2001. Microbially induced sedimentary structures - a new category within the classification of primary sedimentary structures. Journal of Sedimentary Research, A71, 649-656.

Noffke, N., 2010. Geobiology: Microbial mats in sandy deposits from the Archean Era to Today. Springer, p. 193,

Paliwal, B.S., 1998. Felsic volcanics interlayered with sediments of the Marwar Super group at Chhoti Khatu, District Nagour, Rajasthan. Journal of Geological Society of India, 52, 81 $-86$.

Pareek, H.S., 1981. Basin configuration and sedimentary stratigraphy of Western Rajasthan. Journal of Geological Society of India, 22, $517-527$.

Parizot, M., Eriksson, P.G., Aifa, T., Sarkar, S., Banerjee, S., Catuneanu, O., Altermann, W., Bumby, A.J., Bordy, E.M., Van Rooy, J.L., Boshoff, A.J., 2005. Suspected microbial mat-related crack-like sedimentary structures in the Palaeoproterozoic Magaliesberg Formation sandstones, South Africa. Precambrian Research, 138, 274 - 296.

Prasad, B., Asher R., Borgohai, B., 2010. Late Neoproterozoic (Ediacaran) - Early Paleozoic (Cambrian) Acritarchs from the Marwar Supergroup, Bikaner-Nagaur Basin, Rajasthan. Journal of Geological Society of India, 75, $415-431$. 
Rathore, S.S., Venkatesan, T.R., Srivastava, R.K., 1996. Rb-Sr and Ar-Ar systematics of Malani volcanic rocks of southwest Rajasthan: Evidence for a younger post-crystallization thermal event. Proceedings of the Indian Academy of Science (Earth Planetary Science), $105,131-141$.

Rathore, S.S., Venkatesan, T.R., Srivastava, R.K., 1998. Rb-Sr Isotope Dating of Neoproterozoic (Malani Group) Magmatism from Southwest Rajasthan, India: Evidence of Younger PanAfrican Thermal Event by ${ }^{40} \mathrm{Ar}^{39}$ - Studies. Gondwana Research, 2 (2), 271 - 281.

Retallack, G., 2012. Criteria for distinguishing microbial mats and earths, In: Microbial mats in siliciclastic depositional systems through time. SEPM special Publication, 101, 139 152.

Reysenbach, A.L., Cady, S.L., 2001. Microbiology of ancient and modern hydrothermal systems. Trends Microbiology, 9 (2), $79-86$.

Rogov, V.I., Marusin, V., Bykova, N., Goy, Yu., Nagovitsin, K.E., Kochnev, B.B., Karlova, G.A., Grazhdankin, D., 2012. The oldest evidence of bioturbation on Earth. Geology, 40, $395-398$.

Rogov, V.I., Marusin, V., Bykova, N., Goy, Yu., Nagovitsin, K.E., Kochnev, B.B., Karlova, G.A., Grazhdankin, D., 2013. The oldest evidence of bioturbation on Earth: Reply. Geology, e290.

Samanta, P., 2009. Proterozoic siliciclastic sedimentation and sequence building: possible role of microbial mat: Sonia Sandstone, Rajasthan, India. Unpublished Ph.D. Thesis, Jadavpur University, India. p. 303. 
Samanta, P, Mukhopadhyay, S., Mandal, A., Sarkar, S., 2011. Microbial mat structures in rofile: The Neoproterozoic Sonia Sandstone, Rajasthan, India. Journal of Asian Earth ciences, 40, $542-549$.

Sarkar, S., Banerjee, S., Eriksson, P.G., Catuneanu, O., 2005. Microbial mat control on siliciclastic Precambrian sequence stratigraphic architecture: examples from India. Sedimentary Geology, 176, 195 - 209.

Sarkar, S., Banerjee, S., Samanta, P. and Jeevankumar, S., 2006. Micrbial mat-induced sedimentary structures in siliciclastic sediments: examples from the $1.6 \mathrm{Ga}$ Chorhat Sandstone, Vindhyan Supergroup, M.P. India. Journal of Earth system Science, 115 (1), $49-60$.

Sarkar, S., Bose, P.K., Samanta, P., Sengupta, P., Eriksson, P.G., 2008. Microbial mat mediated structures in the Ediacaran Sonia Sandstone, Rajasthan, India, and their implications for Proterozoic sedimentation. Precambrian Research, 162, 248 - 263.

Sarkar, S., Samanta, P., Altermann, W., 2011. Setulfs, modern and ancient: Formative mechanism, preservation bias and paleoenvironmental implications. Sedimentary Geology, 238 (1-2), $71-78$.

Sarkar, S., Samanta, P., Mukhopadhyay, S., Bose, P.K., 2012. Stratigraphic architecture of the Sonia Fluvial interval, India in its Precambrian context. Precambrian Research, 214 - 215, $210-226$.

Sarkar, S., Banerjee, S., Samanta, P., Chakraborty, N., Chakraborty, P.P., Mukhopadhyay, S., Singh, A.K., 2014. Microbial mat records in siliciclastic rocks: Examples from Four Indian Proterozoic basins and their modern equivalents in Gulf of Cambay. Journal of Asian Earth Sciences, 91, 362 - 377. 
Schieber, J., Bose, P.K., Eriksson, P.G., Banerjee, S., Sarkar, S., Altermann, W., Catuneanu, O. (eds.), 2007, Atlas of Microbial Mat Features Preserved within the Siliciclastic Rock Record, Atlases in Geoscience 2, Elsevier, Amsterdam, p. 311.

Schopf, J.W., 1999. Cradle of Life. The Discovery of Earth's Earliest Fossils. Princeton University Press, Princeton, New Jersey, p. 367.

Schopf, J.W., Klein, C., 1992. The Proterozoic Biosphere: A Multidisciplinary Study. Cambridge University Press, p. 1348.

Seilacher, A. 1999. Biomat-related lifestyles in the Precambrian. Palaios, 14, 86 - 93.

Seilacher, A., Pflüger, P., 1994. From biomats to benthic agriculture: a biohistoric revolution. In: Krumbein, W.E., Peterson, D.M., and Stal, L.J., (eds.), Biostabilization of Sediments: Bibliotheks und Informations System der Carl von Ossietzky Universitat Odenburg, pp. $97-105$.

Shanker, R., Bhattacharya, D.D., Pande, A.C., Mathur, V.K., 2004. Ediacaran biota from the Jarashi (Middle Krol) and Mahi (Lower Krol) Formations, Krol Group, Lesser Himalaya, India. Journal of Geological Society of India, 63, 649-654.

Shields, G., 1999. Working towards a new stratigraphic calibration scheme for the Neoproterozoic - Cambrian. Eclogae Geologicae Helvitiae, 92, 221 - 233.

Waggoner, B., 2003. The Ediacaran biotas in space and time. Integrative and Comparative Biology, 43, $104-113$. 